\title{
Immunoreactive Corticotropin-releasing Hormone and Its Binding Sites in the Rat Ovary
}

\author{
George Mastorakos, * Elizabeth L. Webster, ${ }^{*}$ Theodore C. Friedman, ${ }^{*}$ and George P. Chrousos * \\ ${ }^{*}$ Developmental Endocrinology Branch and the ${ }^{\ddagger}$ Laboratory of Developmental Neurobiology, National Institute of Child Health and \\ Human Development, National Institutes of Health, Bethesda, Maryland 20892
}

\begin{abstract}
Corticotropin-releasing hormone (CRH), the principal neuropeptide regulator of pituitary ACTH secretion, is also produced at peripheral inflammatory sites, where it acts as a proinflammatory cytokine, and by the Leydig cell of the testis, where it exerts autocrine inhibition of testosterone biosynthesis. Because key ovarian functions, such as ovulation and luteolysis, represent aseptic inflammatory responses, and because the theca cell is the functional equivalent of the Leydig cell, we explored the CRH presence in the ovary, first, by specific CRH immunohistochemistry of adult cycling female Sprague-Dawley rat ovaries. We detected cytoplasmic immunoreactive CRH (IrCRH) in theca and stromal cells and in cells within the corpora lutea, at all phases of the estrous cycle. Using a specific radioimmunoassay, we measured Ir CRH in extracts of rat ovaries $(0.042-0.126 \mathrm{pmol} / \mathrm{g}$ wet tissue). The mobility of the ovarian IrCRH molecule was similar to that of rat/human CRH by reverse phase HPLC. To investigate the CRH action in the ovary, we identified, characterized, and localized CRH receptors in the rat ovary. Binding was linear with increasing tissue concentration, saturable, and of high affinity. Scatchard analysis of ${ }^{125}$ I-Tyr-ovine $\mathrm{CRH}$ competitive displacement curves indicated a high affinity binding site with a $K_{\mathrm{d}}$ of $\approx 6$ $\mathrm{nM}$ and $\mathrm{a} B_{\max }$ value of $\approx 61 \mathrm{fM} / \mathrm{mg}$ protein. Autoradiographic studies revealed CRH receptors primarily in ovarian theca and stroma. We conclude that IrCRH and CRH receptors are present in rat ovaries, suggesting that this neuropeptide may play a regulatory role in this gonad, perhaps through its proinflammatory properties and/or by participating in the auto/paracrine regulation of steroid biosynthesis. Functional studies are necessary to define the role(s) of CRH in the ovary. (J. Clin. Invest. 1993.92:961-968.) Key words: ovary $\bullet$ inflammation • corticotropin-releasing hormone • follicle • corpus luteum
\end{abstract}

\section{Introduction}

Corticotropin-releasing hormone (CRH), ${ }^{1}$ a 41 -amino acid neuropeptide, was originally isolated in the hypothalamus and named for its property to stimulate anterior pituitary secretion

Address correspondence to Dr. George Mastorakos, National Institutes of Health, Building 10, Room 10N244, 9000 Rockville Pike, Bethesda, MD 20892.

Received for publication 31 December 1992 and in revised form 16 March 1993.

1. Abbreviations used in this paper: $\mathrm{CRH}$, corticotropin-releasing hormone; IrCRH, immunoreactive CRH; r/hCRH, rat/human CRH; oCRH, ovine CRH; TFA, trifluoroacetic acid.

The Journal of Clinical Investigation, Inc.

Volume 92, August 1993, 961-968 of ACTH (1-3). CRH and its receptors were subsequently identified in many extrahypothalamic sites of the central nervous system (4-7), as well as in several peripheral tissues, including active inflammatory sites (8-10) and the testes (11$14)$. In the central nervous system, CRH plays a major coordinative role for the stress response, including activation of the arousal and sympathetic systems and elicitation of stress-related behaviors (15-17). In inflammatory sites, CRH participates as an autocrine/paracrine proinflammatory regulator (8). Although the actual immune/inflammatory cell type that secretes CRH is not known, it is the immune accessory cells (macrophages, tissue fibroblasts, and endothelial cells) that contain immunoreactive CRH (IrCRH) (8-10). In the rat testis, CRH is produced by Leydig cells and appears to play an autocrine inhibitory role on testosterone secretion $(13,14)$.

Ovulation, luteolysis, and, perhaps, follicular atresia, three key ovarian functions, have characteristics of an aseptic/immune inflammatory reaction (18). In addition, resident macrophages constitute a major cellular component of the interstitial ovarian compartment (19-21) and macrophage-generated cytokines, such as interleukin 1, interleukin 6, and TNF $\alpha$, have been demonstrated or suggested to participate in several ovarian functions, such as ovulation, luteinization, and steroidogenesis $(22,23)$. The theca cell in the ovary, on the other hand, has been proposed as the functional equivalent of the Leydig cell in the testis (24). The roles of CRH in inflammation and Leydig cell function suggested that $\mathrm{CRH}$ and its receptors might also be present in the rat ovary and might participate in inflammatory-like phenomena and/or steroidogenesis taking place in the female gonad. In this study we identified, quantitated, and localized CRH and its receptors in the ovaries of mature female Sprague-Dawley rats.

\section{Methods}

\section{Animals}

Adult (2-3 mo old), cycling, female Sprague-Dawley rats were obtained from Harlan-Sprague-Dawley (Indianapolis, IN). Animals were maintained on a 12-h light (lights on at $0600 \mathrm{~h}$ ), 12-h dark cycle, with food and water available ad lib. Normal cycling was verified by daily vaginal smears. Animals were killed by $\mathrm{CO}_{2}$ inhalation, after at least three normal cycles.

\section{Materials}

Synthetic rat/human (r/h) CRH 1-41 was obtained from Peninsula Laboratories Inc. (Belmont, CA) $(25,26)$; HPLC purified ${ }^{125} \mathrm{I}-\mathrm{r} /$ hCRH and ${ }^{125}$ I-Tyr-ovine(o) CRH from New England Nuclear Co. (Boston, MA); cyanogen bromide-activated Sepharose 4B and 3,3diaminobenzidine tetra-hydrochloride from Sigma Chemical Co. (St. Louis, MO); 10\% formalin (Formalde-Fresh) from Fischer Scientific Co. (Pittsburgh, PA); Vectastain ABC kits from Vector Laboratories Inc. (Burlingame, CA); rabbit IgG from Jackson Immunoresearch Laboratories Inc. (West Grove, PA); light green SF from Roboz Surgical Instrument Co. Inc. (Washington, DC); octadecylsilyl-silica (ODS-sil- 
ica) cartridges (C-18 Sep-Pak) from Waters Associates (Marlboro, MA); BCA protein assay kits from Pierce Chemical Co. (Rockford, IL); tritium-sensitive Ultrofilms from LKB (Rockville, MD). The HPLC LKB 2150 system used was purchased from Pharmacia LKB (Piscataway, NJ) and was coupled to a HiPore RP-318 column (C-18) $(5 \times 250 \mathrm{~mm}$ ) obtained from Bio-Rad Co. (Richmond, CA).

\section{Tissue preparation}

The ovaries were dissected immediately after killing. Ovaries prepared for immunohistochemistry were fixed in $10 \%$ formalin and embedded in paraffin. Ovaries prepared for $\mathrm{CRH}$ extraction and radioimmunoassay, CRH binding assay, or autoradiographic mapping of ${ }^{125} \mathrm{I}-\mathrm{T}$ yroCRH-binding sites, were frozen on dry ice immediately and stored at $-70^{\circ} \mathrm{C}$ until assay.

\section{Immunohistochemistry}

Peptide antisera production and purification. Polyclonal antiserum (TS-2) against $\mathrm{r} / \mathrm{hCRH}$ was produced in rabbits as previously described (27). Before use it was affinity-purified by adsorption to synthetic $r / h C R H ~ 1-41$ coupled to cyanogen bromide-activated Sepharose 4B. Briefly, the antiserum was added to the $\mathrm{r} / \mathrm{hCRH}$-Sepharose 4B conjugate ( $1 \mathrm{mg}$ of $\mathrm{r} / \mathrm{hCRH} 1-41 \mathrm{on} 200 \mu \mathrm{ggel}$ ) and incubated at room temperature for $2 \mathrm{~h}$. The suspension was packed in a $4 \times 0.7-\mathrm{cm}$ column and washed with phosphate buffer $(20 \mathrm{mM}$ sodium phosphate, $0.5 \mathrm{M}$ sodium chloride, $\mathrm{pH}$ 7.3) until the $\mathrm{OD}_{280}$ returned to baseline. The elutions obtained from these washings were depleted of anti-r/ hCRH IgG (affinity-negative IgG fraction) and were used in immunohistochemistry staining as controls of the specificity of the anti-r/ hCRH IgG. The antibody bound to the affinity-column (affinity-positive $\mathrm{IgG}$ fraction) was eluted with thiocyanate buffer ( $3 \mathrm{M}$ potassium thiocyanate, $0.5 \mathrm{M}$ ammonium hydroxide) and dialyzed against several changes of cold PBS.

Immunohistochemistry. Tissue specimens were preserved in 10\% formalin. They were embedded in paraffin and sectioned onto gelatincoated microscope slides at a thickness of $6 \mu \mathrm{m}$. Immunoperoxidase staining was performed with the Vectastain $\mathrm{ABC}$ kit (Vector Laboratories), using the manufacturer's suggested protocol and reagents (28, 29). All subsequent procedures took place at room temperature. The sections were deparaffinized with two 5-min washes in xylene and rehydrated by sequential rinses in absolute, $90 \%, 80 \%$, and $70 \%$ ethanol. Endogenous peroxidase activity was exhausted by incubation with $0.3 \%$ peroxide in methanol for $45 \mathrm{~min}$. The sections were then incubated sequentially with $0.1 \%$ BSA in PBS for $20 \mathrm{~min}$ and with diluted goat serum (1/66.7) for $20 \mathrm{~min}$, and in a humid chamber with the affinity-purified rabbit antibody to $\mathrm{r} / \mathrm{hCRH}(50 \mu \mathrm{g} / \mathrm{ml})$, the control, affinity-negative IgG fraction $(50 \mu \mathrm{g} / \mathrm{ml})$ or nonimmune normal rabbit IgG $(50 \mu \mathrm{g} / \mathrm{ml})$. After $40 \mathrm{~min}$, the sections were washed with PBS and incubated with biotinylated goat anti-rabbit $\mathrm{IgG}$ for $30 \mathrm{~min}$. The sections were further washed with PBS and incubated with avidin and a biotinylated horseradish peroxidase complex for $45 \mathrm{~min}$. Finally, the sections were washed and color was developed by immersing sections in a solution of $0.05 \% \mathrm{wt} / \mathrm{vol}$ 3,3-diaminobenzidine tetra-hydrochloride, $0.04 \% \mathrm{wt} / \mathrm{vol}$ nickel chloride, and $0.01 \%$ hydrogen peroxide in $0.05 \mathrm{M}$ Tris, $\mathrm{pH} 7.4$, for $2 \mathrm{~min}$. The sections were counterstained with $0.5 \%$ light green SF. Positive staining was revealed as black-dark green spots, whereas light green color was seen in $\mathrm{r} / \mathrm{hCRH}$-free areas, affinity-negative control sections, and nonimmune normal rabbit IgG control sections. A different staining was also obtained by using the DAB solution without nickel chloride, and Meyer's hematoxyline as nonspecific counterstaining of cell nuclei. In this case, positive staining was revealed as brown color, and nonspecific staining of all cell nuclei as light blue color.

\section{Radioimmunoassay}

Ovarian concentrations of $\mathrm{CRH}$ were measured by radioimmunoassay after acid extraction. Briefly, $10 \mathrm{vol}$ of boiling $2 \mathrm{M}$ acetic acid was added to whole ovaries and the mixture was incubated at $95^{\circ} \mathrm{C}$ for 10 $\min$. Samples were then sonicated on ice for $1 \mathrm{~min}$ and centrifuged at $15,000 \mathrm{~g}$ for $30 \mathrm{~min} .3 \mathrm{vol}$ of acetone was added to the supernatants, and they were again centrifuged at $15,000 \mathrm{~g}$ for $30 \mathrm{~min}$. The supernatants were collected, lyophilized, and reconstituted in radioimmunoassay buffer for measurement, as previously described (30). The CRH antiserum (TS-2) used has been characterized in detail previously (27). ${ }^{125} \mathrm{I}-\mathrm{r} / \mathrm{h} \mathrm{CRH}$ was used as the tracer, and synthetic $\mathrm{r} / \mathrm{hCRH}$ as the standard. The within-assay coefficient of variation and sensitivity were $4 \%$ and $1.05 \mathrm{pmol} /$ liter, respectively.

\section{Reverse phase HPLC}

The samples obtained from acid-extraction of the rat ovaries were reconstituted in $200 \mu \mathrm{l}$ of $0.1 \%$ trifluoroacetic acid (TFA). The sample was then passed through an ODS-silica cartridge (C-18 Sep-Pak; Waters Associates), and the cartridge was washed with $0.1 \%$ TFA, and subsequently by $20 \%$ acetonitrile containing $0.1 \%$ TFA. The peptides were then eluted off the cartridge with $5 \mathrm{ml}$ of $60 \%$ acetonitrile containing $0.1 \%$ TFA. The eluate was lyophilized, reconstituted in $200 \mu \mathrm{l}$ of $0.1 \%$ TFA, and analyzed by HPLC. An aliquot of $180 \mu$ l of the sample was injected into the HPLC column system. Solvent A was $0.1 \%$ TFA and solvent B was $80 \%$ acetonitrile containing $0.1 \%$ TFA. A linear gradient, from 40 to $65 \%$ of solvent $B$ at a flow rate of $1 \mathrm{ml} / \mathrm{min}$, was applied over $45 \mathrm{~min}$. 1-ml samples of the eluate were collected in an automatic collector, lyophilized to dryness, reconstituted with radioimmunoassay buffer, and assayed for CRH content, as described above. A standard of $1 \mu \mathrm{g}$ of synthetic $\mathrm{r} / \mathrm{hCRH}$ was injected after each experiment to determine its chromatography profile.

\section{CRH binding assay}

The affinity and concentration of CRH binding sites were determined from competitive displacement binding experiments, in which rat ovarian tissue homogenates and ${ }^{125} \mathrm{I}-\mathrm{Tyr}-\mathrm{oCRH}$ were incubated with increasing concentrations of unlabeled synthetic $\mathrm{r} / \mathrm{hCRH}$. Both ovaries of the same animal were used to produce each displacement curve. At the time of the assay ovaries were weighed and subsequently homogenized in $20 \mathrm{vol}$ of ice-cold homogenization buffer $(50 \mathrm{mM}$ Tris- $\mathrm{HCl}$, $10 \mathrm{mM} \mathrm{MgCl}_{2}$, and $2 \mathrm{mM}$ EGTA, pH 7.2) using a Polytron (Brinkmann Instruments, Westbury, NY). The homogenate was then centrifuged at $38,000 \mathrm{~g}$ for $10 \mathrm{~min}$, the supernatants were discarded, and the pellets were resuspended to a final concentration of $40 \mathrm{mg}$ tissue wet $\mathrm{wt} / \mathrm{ml}$ in homogenization buffer. $100 \mu \mathrm{l}$ of the membrane preparation were then added to a $1.5-\mathrm{ml}$ polypropylene microtube containing 100 $\mu \mathrm{l}$ of an $\mathrm{r} / \mathrm{hCRH}$ solution ( 12 concentrations ranging from 0 to $1 \mu \mathrm{M}$ ) and $100 \mu \mathrm{l}$ of ${ }^{125} \mathrm{I}-\mathrm{Tyr}-\mathrm{oCRH}(0.2 \mathrm{nM}$ final concentration $)$ in incubation buffer ( $50 \mathrm{mM}$ Tris- $\mathrm{HCl}, 10 \mathrm{mM} \mathrm{MgCl}$, 2 mM EGTA, $0.15 \%$ BSA, 100 kallikrein inhibitor units/ $\mathrm{ml}$ aprotinin, $0.15 \mathrm{mM}$ bacitracin, $\mathrm{pH}$ 7.2). The reaction was allowed to proceed, at room temperature, for $2 \mathrm{~h}$. The membranes were then separated from the incubation medium by centrifugation in a microfuge at $12,000 \mathrm{~g}$ for $8 \mathrm{~min}$. The supernatant was aspirated, the pellets washed gently with $1 \mathrm{ml}$ of PBS containing $0.01 \%$ Triton $\mathrm{X}-100$, and the radioactivity of the pellet was measured in a $\gamma$ counter. The final protein concentration was determined using the BCA protein assay.

\section{Autoradiographic mapping of ${ }^{125}$ I-Tyr-oCRH-binding sites} Slide-mounted tissue sections from ovaries were incubated at room temperature with $0.1 \mathrm{nM}^{125} \mathrm{I}-\mathrm{Tyr}-\mathrm{oCRH}$ in incubation buffer $(50 \mathrm{mM}$ Tris- $\mathrm{HCl}, 10 \mathrm{mM} \mathrm{MgCl} 2,2 \mathrm{mM}$ EGTA, $0.15 \%$ BSA, 100 kallikrein inhibitor units $/ \mathrm{ml}$ aprotinin, $0.15 \mathrm{mM}$ bacitracin, $\mathrm{pH}$ 7.2) for $2 \mathrm{~h}$. To assess nonspecific binding parallel sections were also incubated in the same solution of ${ }^{125} \mathrm{I}-\mathrm{Tyr}-\mathrm{OCRH}$ in the presence of $1 \mu \mathrm{M} \mathrm{r} / \mathrm{hCRH}$. After incubation, tissue sections were washed in PBS containing $0.01 \%$ Triton X-100 at $4^{\circ} \mathrm{C}$ for two consecutive 5-min periods, dipped in a deionized water rinse, and dried rapidly, under a stream of cold dry air. Tritium-sensitive Ultrofilm was apposed to the tissue sections. After 4-5 d of exposure, the autoradiograms were developed, and the tissue was stained with thionin. 

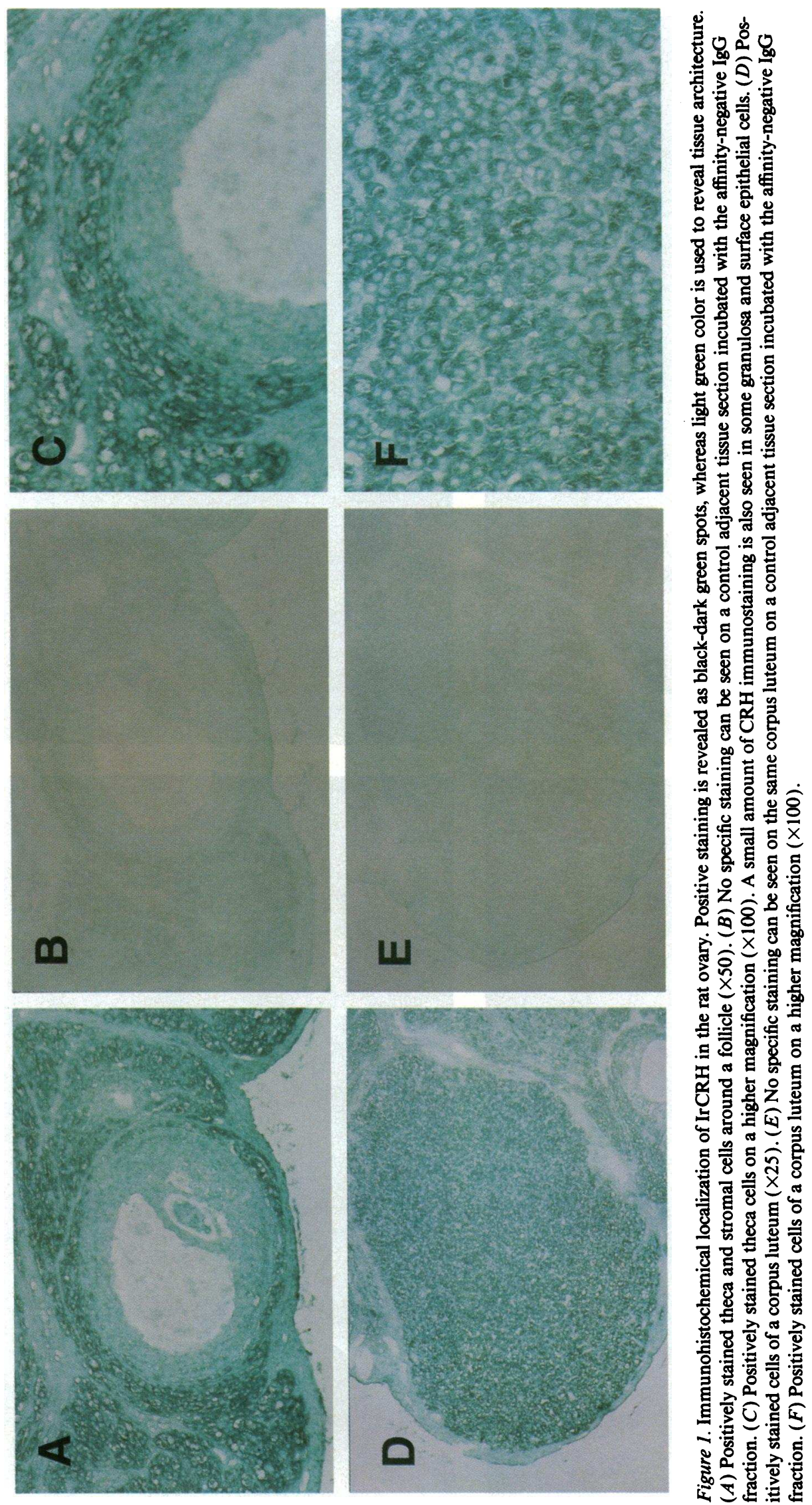

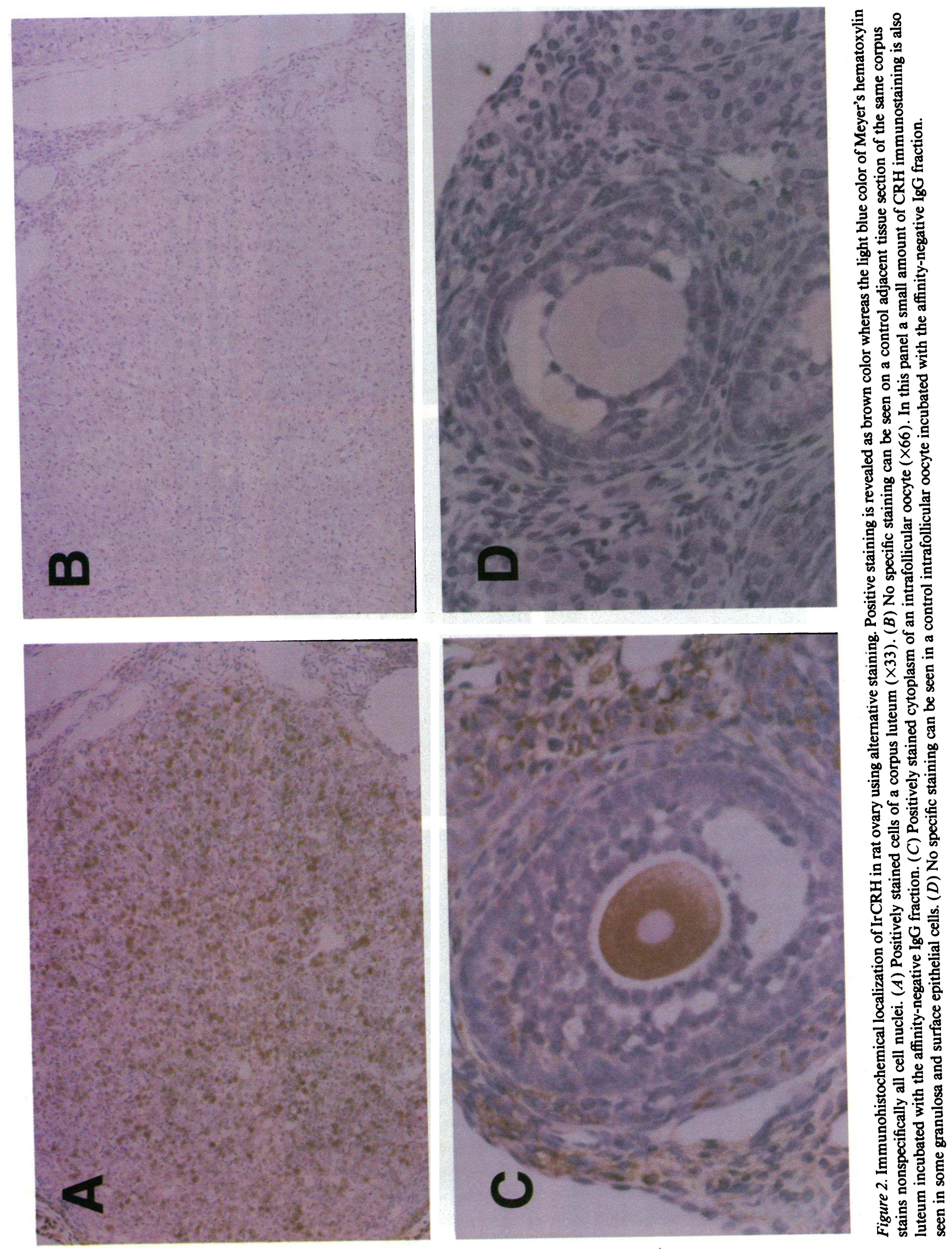
Data analyses

${ }^{125}$ I-Tyr-oCRH binding data were analyzed by the Macintosh-based nonlinear least squares curve fitting computer program LIGAND (31).

\section{Results}

Immunohistochemical detection of IrCRH in the rat ovary. The presence of IrCRH in the ovaries of adult, cycling Sprague-Dawley rats was examined by immunohistochemistry of sections obtained at proestrous, estrous, metestrous, and diestrous. IrCRH was detected in the cytoplasm of theca and stromal cells, regardless of size or maturity of ovarian follicles (Fig. 1, $A$ and $C$ ), as well as in the oocytes of antral follicles (Fig. $2 C$ ) but not the primary oocytes of primordial follicles (data not shown). A small amount of CRH immunostaining was also seen in some granulosa and surface epithelial cells (Figs. $1 C$ and $2 C$ ). IrCRH was also detected in the cytoplasm of a subpopulation of cells within the corpora lutea (Fig. 1, $D$ and $F$, and $2 A$ ). These cells were also found through all stages of corpora lutea maturation and at all phases of the estrous cycle. Since the $\approx 14-\mathrm{d}$ half-life of a rat corpus luteum is longer than the duration of the 4-5-d rat estrous cycle, corpora lutea of different maturation stages were found in the rat ovaries at all phases of the estrous cycle. The IrCRH-containing cells of the corpora lutea, however, were localized progressively from the periphery to the center with advancing maturation and there was less staining for IrCRH in older corpora lutea compared to younger. The maturation/aging of the corpora lutea was based on morphological criteria, including the progressively increasing presence of fibrotic tissue with advancing age of the corpus luteum.

IrCRH measurements and HPLC mobility in rat ovarian extracts. Total ovarian IrCRH content was measured in extracts of rat ovaries at all phases of the estrous cycle. The amount varied between 0.042 and $0.126 \mathrm{pmol} / \mathrm{g}$ of wet tissue. No significant differences in the CRH content were found among ovaries obtained at the different phases of the cycle. Ovarian IrCRH had similar chromatographic mobility to $\mathrm{r} /$ hCRH 1-41, the form produced by the rat and human hypothalamus and the human placenta (Fig. 3). There were also immunoreactive bands with higher mobility than $\mathrm{r} / \mathrm{hCRH}$ $1-41$, indicating the presence of $\mathrm{CRH}$-degradation products and/or aggregates/precursors with different hydrophobicity. To examine whether the ovarian CRH levels reflected or were reflected by circulating CRH levels, we measured plasma concentrations of IrCRH in the same animals. Plasma levels of IrCRH remained $<2.101 \mathrm{pmol} /$ liter $\left(10^{-12} \mathrm{M}\right)$ throughout the estrous cycle.

CRH binding characteristics of rat ovaries. Specific binding of ${ }^{125} \mathrm{I}$-Tyr-oCRH was measured in homogenates of rat ovaries using assay conditions identical to those described for membrane preparations from mouse pituitaries and spleens (32). Specific binding of radiolabeled oCRH was linear with increasing tissue concentrations. Competitive displacement curves of ${ }^{125} \mathrm{I}-\mathrm{Tyr}-\mathrm{OCRH}$ binding in ovarian homogenates incubated with increasing concentrations of $\mathrm{r} / \mathrm{hCRH}$ demonstrated that the specific binding was saturable (Fig. 4). Scatchard analyses using the nonlinear curve fitting program LIGAND (31), revealed a single, high affinity binding site (Fig. 4 , inset). The apparent $K_{\mathrm{d}}$ of ovarian CRH binding sites was $6.34 \pm 2.3 \mathrm{nM}$ (mean \pm SEM, $n=13$ ) and the receptor concentration $\left(B_{\max }\right)$ was $61.17 \pm 15.6 \mathrm{fmol} / \mathrm{mg}$ protein.

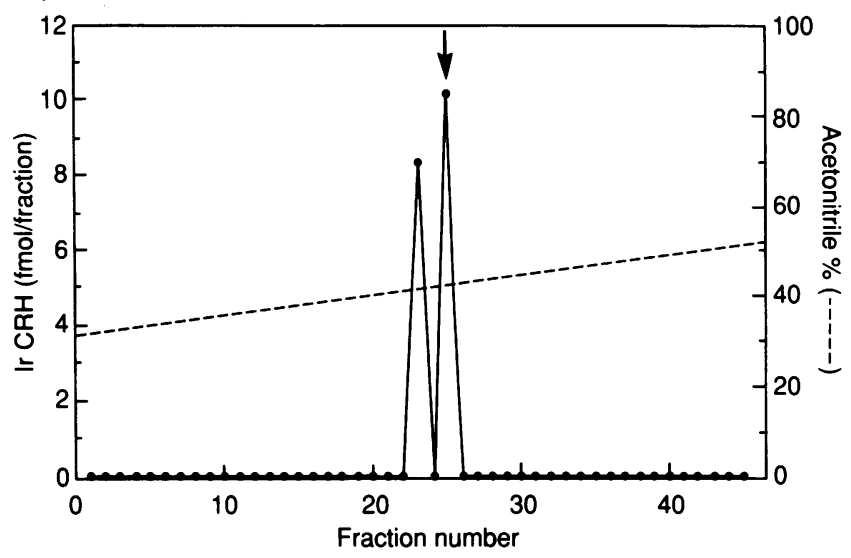

Figure 3. Reverse HPLC characterization of IrCRH extracted from rat ovaries. The amount of CRH in individual fractions was determined by RIA. Synthetic $\mathrm{r} / \mathrm{hCRH} 1-41$ eluted from this column in the fraction indicated by arrow.

Autoradiographic distribution of ${ }^{125}$ I-Tyr-oCRH-binding sites in the rat ovary. The regional distribution of $\mathrm{CRH}$ receptors within the rat ovary was investigated using in vitro autoradiographic techniques. Autoradiograms on tritium-sensitive Ultrofilm (Fig. $5 \mathrm{~B}$ ) were compared to photomicrographs of the same tissue section stained with thionin (Fig. $5 A$ ). CRH receptors were diffusely distributed in ovarian theca and stroma areas surrounding follicles as well as on the cumulus oophorus (Fig. $5 \mathrm{~B}$ ). There was a notable absence of specific binding in the granulosa areas while specific ${ }^{125}$ I-Tyr-oCRH binding sites in the corpora lutea were sparse and not conclu-

\section{I-OCRH BINDING IN RAT OVARY}

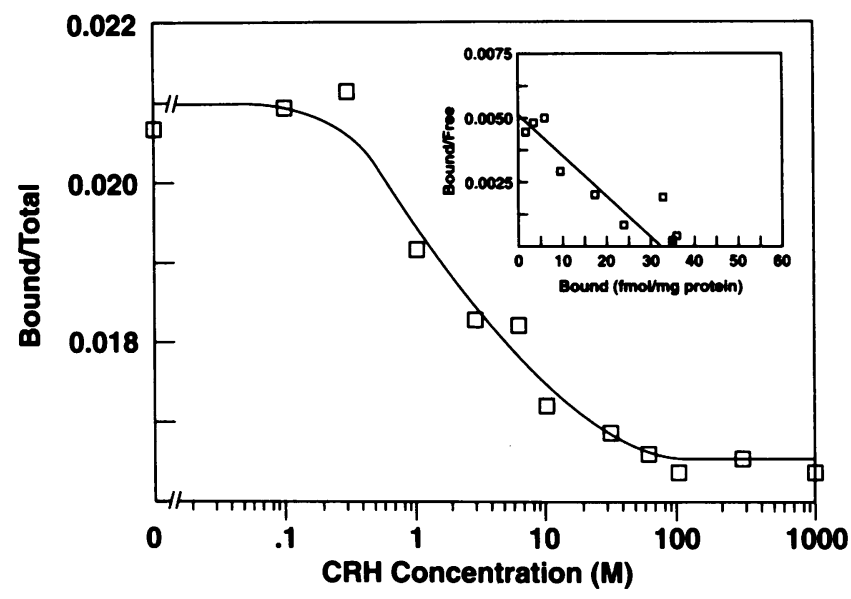

Figure 4. Competitive displacement binding of ${ }^{125} \mathrm{I}-\mathrm{Tyr}-\mathrm{OCRH}$ demonstrating specific binding sites in rat ovarian homogenates incubated in the presence of increasing concentrations of $r / h C R H$. Competitive displacement binding of ${ }^{125}$ I-Tyr-oCRH demonstrates total binding as a function of increasing ligand concentration. The Scatchard plot (see inset) represents specific binding data (total nonspecific binding). Scatchard analysis of the displacement curves by the program LIGAND (31) revealed a single high affinity binding site. The data shown are from a representative experiment. The dissociation constant of $6.34 \pm 2.3 \mathrm{nM}$ and the $B_{\max }$ of $61.17 \pm 15.6 \mathrm{fmol} / \mathrm{mg}$ protein (mean \pm SEM) were determined from the results of 13 independent experiments. 

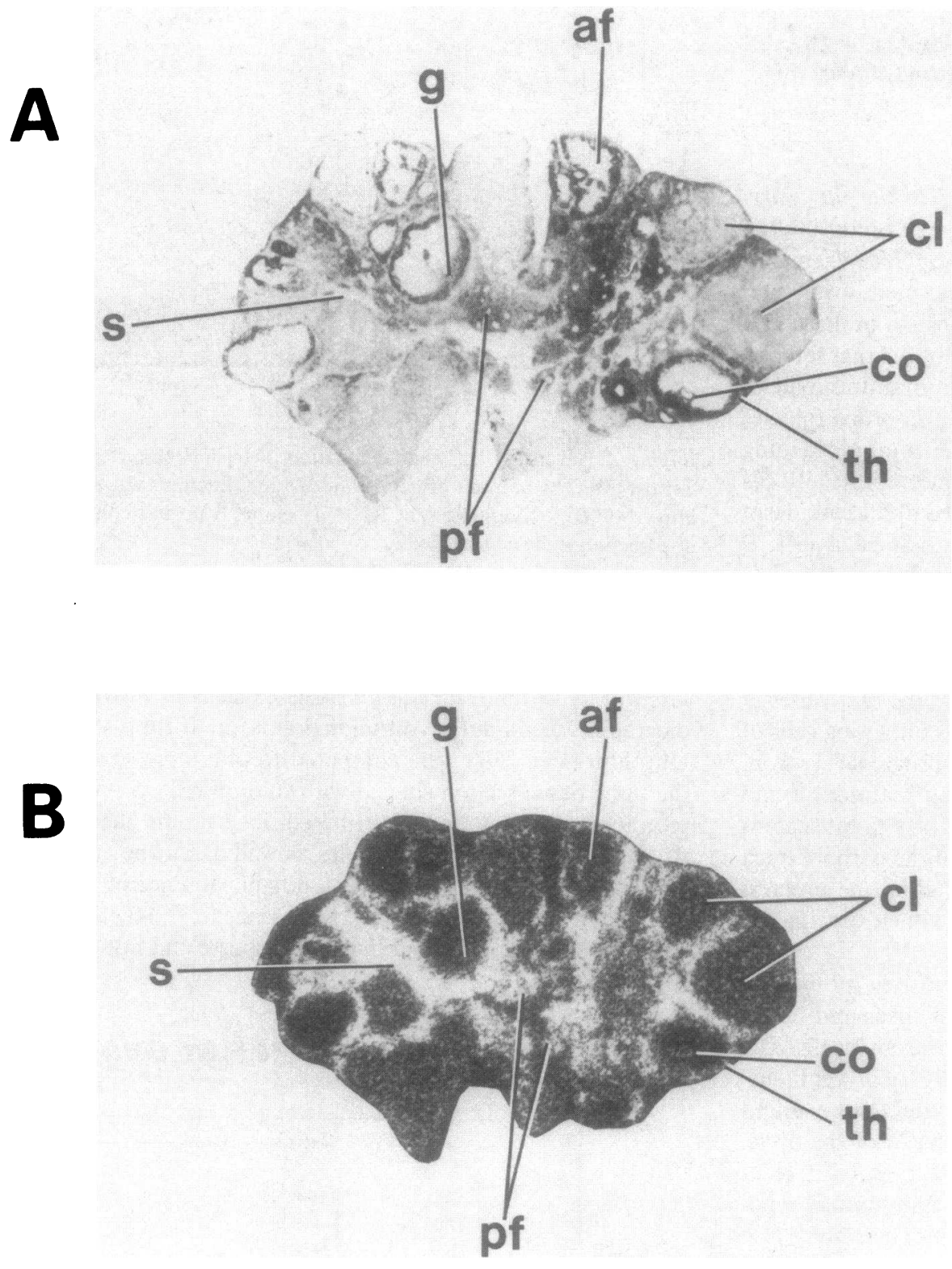

Figure 5. Autoradiographic localization of $\mathrm{CRH}$ receptors in the rat ovary. $(A)$ Bright-field photomicrograph showing the histology of the section of rat ovary used to generate the autoradiogram shown in $B$. After exposure to Ultrofilm as described in Methods, the tissue was stained with thionin. ( $B$ ) Direct print of the autoradiogram generated on tritium-sensitive Ultrofilm, which shows the distribution of autoradiographic grains (white spots) in the section of ovary shown in $A$. $(C)$ Nonspecific binding determined in the presence of $1 \mathrm{mM} \mathrm{r} / \mathrm{hCRH}$ was uniform. Proestrous ovary sections are shown here. Ovaries at all phases of the estrous cycle were examined, however. $s$, stroma; $g$, granulosa; $a f$, atretic follicle; $c l$, corpus luteum; $c o$, cumulus oophorus; th, theca; $p f$, primordial follicles. 
sively seen. Binding in the presence of $1 \mu \mathrm{M} \mathrm{r} / \mathrm{hCRH}$ was low and uniformly distributed (Fig. $5 C$ ).

\section{Discussion}

We have demonstrated that IrCRH is localized in the normal rat ovary. Ovarian IrCRH has similar chromatographic mobility to that of $\mathrm{r} / \mathrm{hCRH} 1-41$, the form produced by the rat and human hypothalamus, rat and human peripheral inflammatory sites, rat Leydig cells, and human placenta $(30,33,26,34$, $8,9,10,13,35)$. The concentrations of IrCRH in the rat ovary $(0.042-0.126 \mathrm{pmol} / \mathrm{g}$ of wet tissue) are similar to those found in the extracts from rat inflammatory tissues $(0.084-0.105$ $\mathrm{pmol} / \mathrm{g}$ of wet tissue $)(8,9)$ or human arthritic joints $(10)$, but are lower than those in the rat testis $(10.719-15.554 \mathrm{pmol} / \mathrm{g}$ of wet tissue) (11). Ovarian CRH could be derived from several sources. First, it might be produced by immune accessory cells normally residing in the ovary, such as macrophages, tissue fibroblasts, and endothelial cells (19-21). CRH mRNA and peptide have been shown in peripheral blood mononuclear cells (36) and in spleen and inflammatory synovia from arthritic Lewis rats (9), whereas the presence of a large number of extravascular macrophages has been well established in the ovarian stroma and corpora lutea (19-21, 37). These macrophages constitute a major cellular component of the interstitial ovarian compartment and are mostly concentrated near perifollicular capillaries (19-21). Second, another potential source of ovarian CRH might be the terminals of postganglionic sympathetic and/or unmyelinated sensory neurons type $C$ and $A \delta$. IrCRH is present at large concentrations in both the sympathetic chain and the dorsal root ganglia, where the cell bodies of these neurons reside $(38,39)$ and is depleted in the rat spinal cord and dorsal root ganglia in response to capsaicin, which is toxic to sensory afferent fibers (40). Third, we must consider that theca and stroma cells, luteinized cells in the corpora lutea, and mature oocytes, all of which contained IrCRH, might also themselves produce this peptide. The plasma is an unlikely source of ovarian $\mathrm{CRH}$, since the levels of this peptide in rat circulation are extremely low (8).

In the present study, we also identified specific, high affinity CRH receptors in homogenates of rat ovaries. ${ }^{125}$ I-Tyr-oCRH binding was saturable and increased linearly with increasing protein concentration. Scatchard analysis of competitive displacement curves revealed a high affinity receptor for CRH in rat ovary $\left(K_{\mathrm{d}}=6.34 \mathrm{nM}\right)$, corresponding to the high affinity receptor previously identified in rat pituitary, hypothalamus, brain (6,7), Leydig cells ( 14) and arthritic synovial tissues (9), and mouse spleen (32). The binding capacity of the rat ovary homogenates $\left(B_{\max }=61.17 \mathrm{fmol} / \mathrm{mg}\right.$ protein $)$ was in the same order of magnitude as that of rat brain cortex homogenates ( $B_{\max }=62.19 \mathrm{fmol} / \mathrm{mg}$ protein $)(32,6)$, one-tenth of that shown in pituitary gland $(41,42)$, and 6 times and 20 times higher than that shown in mouse spleen $\left(B_{\max }=8.74 \mathrm{fmol} / \mathrm{mg}\right.$ protein) (32) and in rat Leydig cells $\left(B_{\max }=2.6 \mathrm{fmol} / \mathrm{mg}\right.$ protein) (14), respectively. We examined the distribution of ${ }^{125}$ I-Tyr-oCRH binding sites by in vitro autoradiography to determine whether CRH receptors are expressed by specific cell types within the ovary. The receptors were primarily found in stroma and theca cells surrounding follicles, regions known to contain macrophages and other immune accessory cells (1921 ), but also in the cumulus oophorus, which might indicate interactions between the IrCRH-containing mature oocyte and cells of the cumulus. There were sparse, dispersed CRH receptors in the corpora lutea, which might also be attributed to presence of resident immune accessory cells in these areas (20, $21,37)$. Neither in the theca/stroma nor in the corpora lutea can we exclude the presence of receptors for $\mathrm{CRH}$ on the actual steroidogenic cells, however.

The presence of CRH and its receptors in the rat ovary raises the question of local involvement of this peptide in ovarian physiology. Two potential roles can be envisioned by extrapolation from existing information. First, ovarian CRH might act as a proinflammatory cytokine during the inflammatory phenomena of the ovarian physiology, which include ovulation, luteolysis, and, perhaps, follicular atresia. Theca CRH might participate in the actual process of ovulation and in the vascularization of the granulosa during formation of the corpus luteum, when eosinophils and T lymphocytes chemoattracted into the follicle produce lymphokines that attract and activate monocytes/macrophages (43). During luteolysis, phagocytically active macrophages appear to be involved in digestion of luteal cells $(19,44)$. The general presence of $\mathrm{CRH}$ in peripheral blood mononuclear leucocytes (36) and other inflammatory cells, and its proinflammatory properties $(8-10)$ suggest that the peptide of the corpora lutea might be involved in the immune aspects of luteolysis. Ovarian CRH might exert its inflammatory actions directly and/or indirectly via cytokines, since many of the effects of this neuropeptide on peripheral blood mononuclear cells are mediated by IL-1 $\beta$ (45). The second role that might be ascribed to ovarian CRH is its participation in ovarian steroid hormone biosynthesis, in analogy to its effect on testosterone biosynthesis by Leydig cells $(13,14)$. Again, this effect might be direct or mediated by local secretion of cytokines and/or lipid mediators of inflammation, known to influence hormonogenesis. Indeed, IL-1 mediates inhibition of hCG-stimulated androsterone accumulation by cultured whole rat ovarian dispersates and might, thus, be involved in the actions of CRH (46). Further studies are needed to define the biological role(s) of ovarian CRH.

\section{Acknowledgments}

E. L. Webster is supported by the pharmacology research associate program (PRAT fellowship) of the National Institute of General Medical Sciences.

\section{References}

1. Saffran, M., A. V. Schally, and B. G. Bentey. 1955. Stimulation of the release of corticotropin from the adenohypophysis by a neurohypophysial factor. Endocrinology. 57:439-444.

2. Guillemin, R., and B. Rosenberg. 1955. Humoral hypothalamic control of anterior pituitary: a study with combined tissue cultures. Endocrinology. 57:599607.

3. Vale, W., J. Spiess, C. Rivier, and J. Rivier. 1981. Characterization of a 41-residue ovine hypothalamic peptide that stimulates secretion of corticotropin and $\beta$-endorphin. Science (Wash. DC). 213:1394-1397.

4. Fischman, A. J., and R. L. Moldow. 1982. Extrahypothalamic distribution of CRF-like immunoreactivity in the rat brain. Peptides (Elmsford). 1:149-153.

5. Swanson, L. W., P. E. Sawchenko, J. Rivier, and W. Vale. 1983. Organization of ovine corticotropin-releasing factor immunoreactive cells and fibers in the rat brain: an immunohistochemical study. Neuroendocrinology. 36:165-186.

6. Wynn, P. C., R. L. Hauger, M. C. Holmes, M. A. Millan, K. J. Catt, and G. Aguilera. 1984. Brain and pituitary receptors for corticotropin releasing factor: localization and differential regulation after adrenalectomy. Peptides (Elmsford). 5:1077-1084. 
7. De Souza, E. B. 1987. Corticotropin-releasing factor receptors in the rat central nervous system: characterization and regional distribution. J. Neurosci. 7:88-100.

8. Karalis, K., H. Sano, J. Redwine, S. Listwak, R. L. Wilder, and G. P. Chrousos. 1991. Autocrine or paracrine inflammatory actions of corticotropinreleasing hormone in vivo. Science (Wash. DC). 254:421-423.

9. Crofford, L. J., H. Sano, K. Karalis, E. L. Webster, E. A. Goldmuntz, G. P. Chrousos, and R. L. Wilder. 1992. Local secretion of corticotropin-releasing hormone in the joints of Lewis rats with inflammatory arthritis. J. Clin. Invest. 90:2555-2564.

10. Crofford, L. J., H. Sano, K. Karalis, T. C. Friedman, H. R. Epps, E. F. Remmers, P. Mathern, G. P. Chrousos, and R. L. Wilder. 1993. Corticotropin-releasing hormone in synovial fluids and tissues of patients with rheumatoid arthritis and osteoarthritis. J. Immunol. In press.

11. Yoon, D. J., C. Sklar, and R. David. 1988. Presence of immunoreactive corticotropin-releasing factor in rat testis. Endocrinology. 122:759-761.

12. Audhya, T., C. S. Hollander, D. H. Schlesinger, and B. Hutchinson. 1989. Structural characterization and localization of corticotropin-releasing factor in the testis. Biochem. Biophys. Acta. 995:10-16.

13. Fabbri, A., J. C. Tinajero, and M. L. Dufau. 1990. Corticotropin-releasing factor is produced by rat Leydig cells and has a major local antireproductive role in the testis. Endocrinology. 127:1541-1543.

14. Ulisse, S., A. Fabbri, and M. L. Dufau. 1989. Corticotropin-releasing factor receptors and actions in rat Leydig cells. J. Biol. Chem. 264:2156-2163.

15. Chrousos, G. P., and P. W. Gold. 1992. The concepts of stress and stress system disorders. JAMA (J. Am. Med. Assoc.). 267:1244-1252.

16. Brown, M. R., L. A. Fisher, J. Spiess, C. Rivier, J. Rivier, and W. Vale. 1982. Corticotropin-releasing factor: actions on the sympathetic nervous system and metabolism. Endocrinology. 111:928-931.

17. Brown, M. R. 1991. Neuropeptide-mediated regulation of the neuroendocrine and autonomic responses to stress. In Stress, Neuropeptides and Systemic Disease. J. McCubbin, P. Kaufman, and C. Nemeroff, editors. Academic Press, New York. 73-93.

18. Espey, L. L. 1980. Ovulation as an inflammatory reaction: a hypothesis. Biol. Reprod. 22:73-106.

19. Bulmer, D. 1964. The histochemistry of ovarian macrophages in the rat. J. Anat. 98:313-319.

20. Hume, D. A., D. Halpin, H. Charlton, and S. Gordon. 1984. The mononuclear phagocyte system of the mouse defined by immunohistochemical localization of antigen F4/80: macrophages of endocrine organs. Proc. Natl. Acad. Sci. USA. 81:4174-4177.

21. Katabuchi, H., Y. Fukumatsu, and H. Okamura. 1989. Immunohistochemical and morphological observations of macrophages in the human ovary. In Growth Factors and the Ovary. A. N. Hirshfield, editor. Plenum Publishing Corp., New York. 409-413.

22. Adashi, E. Y. 1989. Cytokine-mediated regulation of ovarian function: encounters of a third kind. Endocrinology. 124:2043-2045. (Editorial.)

23. Adashi, E. Y. 1990. The potential relevance of cytokines to ovarian physiology: the emerging role of resident ovarian cells of the white blood cell series. Endocr. Rev. 11:454-464.

24. Erickson, G. F., D. A. Magoffin, C. A. Dyer, and C. Hofeditz. 1985. The ovarian androgen producing cells: a review of structure/function relationships. Endocr. Rev. 6:371-399.

25. Vale, W., C. Rivier, M. R. Brown, J. Spiess, G. Koob, L. Swanson, L. Bilezikjian, F. Bloom, and J. Rivier. 1983. Chemical and biological characterization of corticotropin releasing factor. Recent Prog. Horm. Res. 39:245-270.

26. Shibahara, S., Y. Morimoto, Y. Furutani, M. Notake, H. Takahashi, S. Shimizu, S. Horikawa, and S. Numa. 1983. Isolation and sequence analysis of the human corticotropin-releasing factor precursor gene. EMBO (Eur. Mol. Biol. Organ.) J. 2:775-779.

27. Schurmeyer, T. H., P. C. Avgerinos, P. W. Gold, W. T. Gallucci, T. P. Tomai, G. B. Cutler, Jr., D. L. Loriaux, and G. P. Chrousos. 1984. Human corticotropin-releasing factor in man: pharmacokinetic properties and dose-response of plasma adrenocorticotropin and cortisol secretion. J. Clin. Endocrinol \& Metab. 59:1103-1108.
28. Hsu, S. M., L. Raine, and H. Fanger. 1981. A comparative study of the peroxidase-antiperoxidase method and an avidin-biotin complex method for studying polypeptide hormones with radioimmunoassay antibodies. Am. J. Clin. Pathol. 75:734-738.

29. Hsu, S. M., L. Raine, and H. Fanger. 1981. Use of avidin-biotin-peroxidase complex $(\mathrm{ABC})$ in immunoperoxidase techniques: a comparison between $\mathrm{ABC}$ and unlabeled antibody (PAP) procedures. J. Histochem. Cytochem. 29:577-580.

30. Calogero, A. E., R. Bernardini, A. N. Margioris, G. Bagdy, W. T. Gallucci, P. J. Munson, L. Tamarkin, T. P. Tomai, L. Brady, P. W. Gold, and G. P. Chrousos. 1989. Effects of serotonergic agonists and antagonists on corticotropinreleasing hormone secretion by explanted rat hypothalami. Peptides (Elmsford). 10:189-200.

31. Munson, P. J., and D. Rodbard. 1980. LIGAND: a versatile computerized approach for characterization of ligand binding systems. Anal. Biochem. 107:220-239.

32. Webster, E. L., and E. B. De Souza. 1988. Corticotropin-releasing factor receptors in mouse spleen: identification, autoradiographic localization, and regulation by divalent cations and guanine nucleotides. Endocrinology. 122:609-617.

33. Carey, R. M., S. K. Varma, C. R. Drake, M. O. Thorner, K. Kovacs, J. Rivier, and W. Vale. 1984. Ectopic secretion of corticotropin-releasing factor as a cause of Cushing's syndrome. N. Engl. J. Med. 311:13-20.

34. Suda, T., N. Tomori, F. Tozawa, H. Demura, K. Shizume, T. Mouri, Y. Miura, and N. Sasano. 1984. Immunoreactive corticotropin and corticotropinreleasing factor in human hypothalamus, adrenal, lung cancer, and pheochromocytoma. J. Clin. Endocrinol. \& Metab. 58:919-924.

35. Grino, M., G. P. Chrousos, and A. N. Margioris. 1987. The corticotropin releasing hormone gene is expressed in human placenta. Biochem. Biophys. Res. Commun. 148:1208-1214.

36. Stephanou, A., D. S. Jessop, R. A. Knight, and S. L. Lightman. 1990. Corticotropin-releasing factor-like immunreactivity and mRNA in human leukocytes. Brain Behav. Immun. 4:67-73.

37. Kirsch, T. M., A. C. Friedman, R. L. Vogel, and G. L. Flickinger. 1981. Macrophages in corpora lutea of mice: characterization and effects on steroid secretion. Biol. Reprod. 25:629-638.

38. Merchenthaler, I., M. A. Hynes, S. Vigh, A. V. Schally, and P. Petrusz. 1983. Immunocytochemical localization of corticotropin releasing factor (CRF) in the rat spinal cord. Brain Res. 275:373-377.

39. Udelsman, R., J. P. Harwood, M. A. Millan, G. P. Chrousos, D. S. Goldstein, R. Zimlichman, K. J. Catt, and G. Aguilera. 1986. Functional corticotropin releasing factor receptors in the primate peripheral sympathetic nervous system. Nature (Lond.). 319:147-150.

40. Skofitsch, G., G. S. Hamill, and D. M. Jacobowitz. 1984. Capsaicin depletes corticotropin-releasing factor-like immunoreactive neurons in the rat spinal cord and medulla oblongata. Neuroendocrinology. 38:514-517.

41. Perrin, M. H., Y. Haas, J. E. Rivier, and W. W. Vale. 1986. Corticotropinreleasing factor binding to the anterior pituitary receptor is modulated by divalent cations and guanyl nucleotides. Endocrinology. 118:1171-1179.

42. Wynn, P. C., J. P. Harwood, K. J. Catt, and G. Aguilera. 1985. Regulation of corticotropin-releasing factor (CRF) receptors in the rat pituitary gland: effects of adrenalectomy on CRF receptors and corticotroph responses. Endocrinology. 116:1653-1659.

43. Murdoch, W. J., L. E. Steadman, and E. L. Belden. 1988. Immunoregulation of luteolysis. Med. Hypotheses. 27:197-199.

44. Lobel, B., R. Rosenbaum, and H. Deane. 1961. Enzymic correlates of physiological regression of follicles and corpora lutea in ovaries of normal rats. Endocrinology. 68:232-247.

45. Kavelaars, A., R. E. Ballieux, and C. J. Heijnen. 1989. The role of IL-1 in the corticotropin-releasing factor and arginine-vasopressin-induced secretion of immunoreactive $\beta$-endorphin by human peripheral blood mononuclear cells. $J$. Immunol. 142:2338-2342.

46. Hurwitz, A., D. W. Payne, J. N. Packman, C. L. Andreani, C. E. Resnick, E. R. Hernandez, and E. Y. Adashi. 1991. Cytokine-mediated regulation of ovarian function: interleukin-1 inhibits gonadotropin-induced androgen biosynthesis. Endocrinology. 129:1250-1256. 